\title{
Islamic Late Antiquity and Fath: the Effect as Cause
}

\section{Antigüedad Tardía islámica y Fatḥ: efectos tomados por causas}

\author{
Emilio González Ferrín ${ }^{1}$ \\ Universidad de Sevilla (España)
}

Recibido: 25-10-18

Aprobado: 14-12-18

\section{Resumen}

El objetivo de este trabajo es reconsiderar el concepto de conquista islámica -Fath- en tanto que medio para la expansión islámica, así como contestar el modo en que tendemos a describir una serie de acciones bélicas en Oriente Medio y en el Mediterráneo calificándolas a veces de "islámicas" y otras veces de "árabes". Se destacará lo inapropiado de considerar históricamente todas estas conquistas -futūh-, pertenecientes al ámbito de lo literario en las muy tardías crónicas árabes. Tales narraciones establecen una cadena de eventos interrelacionados y centralizados en una sola t simple causa: la matriz del Islam, siendo éste el modo erróneo en que suelen considerarse y enseñarse los orígenes del Islam.

Palabras-clave: El primer Islam, Antigüedad Tardía islámica, Atasco epistemológico, Historiología.

\footnotetext{
${ }^{1}$ (ferrin@us.es) Emilio González Ferrín es islamólogo e imparte docencia sobre estudios árabes e islámicos en la Universidad de Sevilla. Ha publicado numerosos artículos y una decena de monografías sobre temas de cooperación cultural con el mundo árabe y el Islam, entre los que destacan Diálogo Euro-Árabe (1997), El Modernismo Islámico (2000) o La palabra descendida, una lectura intelectual del Corán que fue galardonada con el Premio Internacional de Ensayo Jovellanos 2002. En el ámbito de las literaturas y religiones comparadas ha publicado La angustia de Abraham (2013) -traducida al portugués en 2018-, continuación de su estudio Historia General de Alándalus (2006) -con varias ediciones en español y francés-, así como Cuando fuimos árabes (2019).
} 


\begin{abstract}
The aim of this paper is to reconsider the very concept of Fath -conquestas means of early Islamic expansion as well as the way we tend to describe so many war actions in the Middle East and the Mediterranean region, the seventh and the eighth centuries, sometimes as Islamic, sometimes as Arab futūh -conquests-. It will also focus on the inappropriateness of considering those several war actions - those futūh, to literary effects in later Arabic chronicles- as a chain of subsequent events, interrelated, centralized and derived from a single cause, i.e. the matrix of Islam, as it is usually considered and taught.
\end{abstract}

Key-words: Early Islam, Islamic Late Antiquity, Conceptual drowsiness, Historiology.

One late evening Nasreddin found himself walking home. It was only a very short way and upon arrival he can be seen to be upset about something. Alas, just then a young man comes along and sees the Mullah's distress. "Mullah, pray tell me: What is wrong?" "Ah, my friend, I seem to have lost my keys. Would you help me search them? I know I had them when I left the tea house". So, he helps Nasreddin with the search for the keys. For quite a while the man is searching here and there but no keys are to be found. He looks over to Nasreddin and finds him searching only a small area around a street lamp. "Mullah, why are you only searching there?" "Why would I search where there is no light?"

1.

The aim of this paper is to reconsider the very concept of Fath -conquestas means of early Islamic expansion as well as the way we tend to describe so many war actions in the Middle East and the Mediterranean region, the seventh and the eighth centuries, sometimes as Islamic, sometimes as Arab futūh -conquests-. It will also focus on the inappropriateness of considering those several war actions - those futūh, to literary effects in later Arabic chronicles- as a chain of subsequent events, interrelated, centralized and derived from a single cause, i.e. the matrix of Islam, as it is usually considered and taught (Reinhart 2003:28).

I will try to highlight a certain epistemological jam in which we all participate concerning this, produced by several causes: the mixing of religion, culture and politics throughout history (specifically while dealing with Islam), the incorrectness of preferring secondary -later- sources and not primary ones while constructing a historical narrative about early Islam -Bashear uses here riwāya in Arabic, like today's 'novel' (1984)-, some unrelenting considerations of Islam as an anachronistic collective identity regardless of time and 
geography, the additional problem of leaded and induced translations, the vivid and interesting debate about who-did-what-and-when (Muslims, Hagarens, believers...?), as well as the scientific barrier that appear with the excesses of taxonomy, either in the separation of disciplines or in the insurmountable division of ages into labels such 'Late Antiquity' and 'Middle Ages'. In order to encompass these two latter categories, we propose the use of the expression Islamic Late Antiquity, for instance (Sizgorich 2004:9), and the overarching possible interpretative procedure of Historiology. This is not for the purpose of despising Historiography and so many other possible sources of primary historical documentation, but to promote their enhancement and reasonable reading in inter-connection.

This aims to be a thought-provoking paper, and not a highly analytical one, or an attempt at representing the state of the art about the matter. It is just an afterthought motivated by some suspicions of cognitive bias, while dealing with the very ultimate meaning of early Islam.

\section{Epistemological jam}

The already mentioned epistemological jam -conceptual drowsiness, as Reinhart calls it (2003:25)- while dealing with early Islamic History, probably comes from a 'presumption of logic' in a process, defining this as general expectations about the orderliness of what occurred (Weick 1987:225). In a common and natural -not necessarily scientific or honest- procedure of retrospective narrative, facts are related as motivated by a clear historical will, as if any significant step were planning the following ones, foreseeing and accepting the final auto-justification -self-interpretation- of a certain transcendental later step as the explanation of all the previous ones. From that point of view, for instance, a certain historical fact -let's say, the foundation of the city of Baghdad around year 762- is taken as the final step of a long chain of induced events. The blossom of a literary genre some time later -futūh- as part of a genuine cultural outbreak related to the already learned and well-bred Arabic language -fushà- will explain the long and chaotic century and a half passed before 762 as a coherent and linear path starting in year 622 in between Mecca and Medina -at those times, named Yathrib-. No matter how inconsistent the minimalistic reading of an overwhelming maximalist unrest in the Middle East may appear from a Historiological point of view, or how erroneous the jump from Medina to Damascus reveals itself without changing the subject of the sentence, for instance. Moreover, it may appear equally inconsistent to narrate in connection the eclipse of Damascus and the zenith of Baghdad. Again: everything will be patched together, later on, by tinkering the chronicles. 
The 'presumption of logic' in this historical process -from Medina to Baghdad- depends on an unprecedented explanation: a religious system Islam- expanded itself through a combination of astonishing persuasiveness and unstoppable military power to give birth to a cultural and political system Islam- which, in turn, broke with the above in History to the extent of starting a new age: the Middle Ages. Assuming that conclusion is indeed an unsurpassable case of circular reasoning: the undeniable existence of a new cultural system -Islam-, in the absence of any other formative explanation, leads us to believe in its miraculous beginnings - prophetical call and motivated conquest- that, in turn, demonstrate its validity in the realizations of that later cultural system -medieval Islam-.

The epistemological jam, the conceptual drowsiness in our subject -early Islam, futūh- is motivated precisely by some different facts: first of all, because the entire interpretation is practically based on he Arabic chronicles -secondary sources- elaborated long after that 'foundational' date of 762. Secondly, there are earlier chronicles - primary sources- in several languages (including even timid partial appearances in Arabic), but they have been systematically interpreted in the light of those late complete Arabic chronicles. And the main concern here is usually not actual feasibility or contrast of events related but concordances between old and later chronicles. Thirdly, that at this point it is eventually impossible to change the paradigm or to deny the major premise commonly accepted: Islam expanded by the power of the sword, meaning that its 'nature' may be related to this fact, to this 'matrix essence'. Nevertheless, this interpretation is unconvincing under any Historiological point of view Historiology, qualitative research, versus Historicity (Heidegger 2011:77)-, that is to say, through comparative, contrastive and logical lenses applied to the comprehension of History, because too many factors and events tend to appear compressed in a single line with its ramifications. As we said, his interpretation implies that Islam would have been at the beginning a sort of self-propelled entity, like a powerful historical peg-top flowing over its steel tip from Mecca to Baghdad, and also from Poitiers - westbound- to Khurasan -eastbound- and beyond.

Through Historiological lenses, in contrast, the pretended blinding simplicity of a miraculous chain of futūh become a very different and more complicated scenario with different denominations of peoples involved in war actions and cultural encounter, previous and long-term religious disputes between not so easily distinguishable communities, withdrawal of empires, collapse of dynasties, migrations, architectural and artistic continuity, competitive minting of coins, bypassing of classical trade routes, establishing a maximalist commercial system... In short, a combination of factors that may lead us to turn away from the light in order to avoid, precisely, the street-light 
effect so clearly illustrated in the opening tale from Nasreddin: perhaps, a good way of describing the whole matter is through several questions and not through an all-in-one answer. Or maybe that good way could start trying to avoid the simplicity of a unique explanation. Because that unique explanation can easily crumble through the classical petitio principii or 'dodging the question': what do we mean by Islamic or Arab Fath? Do we mean by Arabs just some kind of heterogeneous non-metropolitan inhabitants, 'people(s) of the $\operatorname{desert}(\mathrm{s})$ ', or rather a clear nationalistic/idiomatic denomination?

Do we mean by Islamic the existence and historical extrapolation/ definition at those times of a new religious system? Can we really depart from a third-person-plural consideration of what came in the Middle East -They arrived-? Who could distinguish confessional, linguistic, racial, high political or economic motivations in the welter and genuine hodgepodge that characterized those times and lands, to the point of ruling the emergence from the desert of a new -huge- historical actor? And, the most important thing: given a multiplicity of names for the main actors that lean out from elder chronicles, who can still translate/interpret the whole time of changes as a single (centralized) process of Arab or Islamic Futūhn? The literary explanation of the whole process is Faith. It is the faith (normally historiographical, though occasionally religious), and also the stereotypical consideration of others and other times: 'the proverbial oral memory of the Arabs', the 'antique flavor of that document' (despite being a late copy)... It is faith what fills the gaps and injects narrative coherence to a heterogeneous bunch of stories with which the literate Middle East described the collapse of two empires and some other catastrophes wrapped up in a genuine apocalyptical language.

At the very end, trying to visualize the whole interpretation of the facts related to early Islam, as we can read them from the chronicles, even if we simply want to establish connections between the two waves of testimonies and not to understand what could have really happened (being those two waves of documents as follows: 1- pre-Islamic chronicles till mid eight century, and 2-Arabic chronicles from then on), all those materials can be classified into two Narratology groups due to semantic and subject considerations: in pre-Islamic testimonies, They are coming, bringing the disaster (although, I said, there are different subjects, various They), while in the Arabic chronicles, We succeeded. The importance does not rely on the explicit appearance of grammatical subjects, but on the alien consideration of evil in the first chronicles -chaos, disaster- and the correlative feeling of affinity with those elder powerful warriors in the Arabic chronicles. The self-alienation is voluntary in the second wave of documents, their authors preferring to come from the outside than feeling themselves in continuation, as inheritors of a previous culture/system. 
Moreover, those powerful warriors present themselves as voiceless till the emergence of Arabic chronicles, and those chaos-and-disaster descriptions in the pre-Islamic chronicles inherit and continue the same literary theme about earlier Persian offensives. The plot summary of the whole set is a two-movement structure separated first of all by the subject, and also by idiom, language, the sociological situation, and so many other factors that offer the appearance of a genuine change of Age in between, although they are indefectibly presented intertwined. Again: 1- a literary systole of apocalyptical conception due to hard times (pre-Islamic chronicles); and 2- a diastole of Salvation, triumphal testimony (Arabic chronicles): a genuine Heilsgeschichte, perhaps even clearer than in religious literature strictly speaking. The rising and 'marching People', following and accomplishing the will of God, have even less boundaries in those Arabic chronicles than in the Exodus itself. Furthermore, the denomination of those second 'diastole chronicles' is evident: Arabic chronicles are those written completely in Arabic. The first denomination is not that clear and is chosen by exclusion: I refer to this documentation as pre-Islamic chronicles for the single reason that they do not mention Islam. A choice by exclusion that could also be considered as keystone in the interpretation of early Islam: a time still without Islam.

The epistemological jam we are dealing with, the confusion created by ignoring the natural complexity of such a 'longue durée' process, is not just a question of comprehensive difficulties or explanatory deficiencies. Nothing is more common in sciences than recognizing a difficulty or the lack of a possible overall explanation from which we start. No, the problem here is precisely the contrary: the excess of (invented) clarity. The already mentioned street-light effect.

\section{Overloading terms}

To a certain extent, there is no possible explanation for Islam, but Islam is rather the explanation itself. In its early stages, it didn't do anything but 'was done'. I mean that Islam is historically recognizable as such only in a later stage. As a historical product that just started to function as such much later. In any case, very long after any usual conventional date (622). In my opinion, this heterogeneous period is precisely the one that should establish the chronological limits of early Islam: beginning in a boiling world when Late Antiquity showed itself as an 'Age of Spirituality' (Weitzmann 1979) through the assignation of theological labels to social and political controversies, and ending in the process of pre-medieval decantation that did spread over the whole Middle East and Central Asia; a process of genuine 'religious nationalism' in the 
mid eighth century, when the city of Baghdad -still City of Peace- copied the Central Asian royal palace-city plan from other eastern neighboring 'religious nationalisms' (Beckwith 2009:24). These are probably the limits of early Islam as the formative period of Islam till its historical birth (and not its first steps once born), and those are the centuries we should refer to as Islamic Late Antiquity in similar considerations, between year 300 and year 750 (roughly speaking): not because Islam would have been born -let's say- when the Roman capital moved to Constantinople, and the whole Middle Eastern hot spring intensified its socio-religious-political multifaceted capacities, but because those were the times in which the seeds of what would become Islam were planted.

That is why I tend to assume that Islam is not at all the cause of a convulsed era in the Middle East and the Mediterranean basin, but its final effect. Its decantation when the dust settled. That is why I tend to consider the Arab or Islamic futūh as a literary genre (Arié 1984:368) and not as a means of expansion. And the long period of war actions that motivates the appearance of this genre is no other than the disorder before the Islamic order ('City of Peace', we said: not of 'Victory' or 'Loot'). Through a Historiological lens, a good metaphorical comparison would be expressed as follows: to assume that Islam expanded itself throughout history and geography before having its proper name and its institutional first person singular is like considering that it is the mill which creates the wind.

As an overloaded term, Islam designates at least three things: 1- a religious system (the most complicated to spin off, because it is an enormous living organism moving through history with a lot of sensitivities accumulated. And having in mind that this movement is the key and the very core of history, I always say that any attempt to clearly describe a portion of history is like trying to photograph a galloping horse while you're galloping on the back of another horse. Two movements and a huge mismatch between them, ensuring a blurred picture: the first horse, the past parading; and the second one, the present pushing and pressing. Because no one can pretend today a quiet, dry and cold reception of any aspect or account of a given religion in the past, say Islam for example). 2- A civilization (a priori, the easiest to deal with, because you just have to collect cultural achievements, with benefit of inventory. Nevertheless, it's not that easy to make everyone understand this apparent simplicity. Let's take into account, for instance, the Islamic civilizing component of Spain or even Europe to a great extent, or perhaps the parallel Islamic one in India, or the Christian one in Egypt or Turkey. Do the current populations of those countries accept wholeheartedly the aseptic separation between past fertile civilizations and current religious synonymy?). 3- A sociological component, (a part of the world, or -perhaps more correctly- some communities all over the world, to the point that it is already absurd to keep on talking about clear geographical 
separations. These communities are inserted in competitive growth with so many discrepancies that it is simply a joke to start a sentence by saying 'Islam is this'. How to conciliate, for instance, the 'long civil war of Islam' between Chiism and Sunnism (Sfeir 2013), a key to interpret current times much more tuned than pretended phobias to the West?).

It is with all this (and much more) in mind that we have to deal with while thinking and writing about early Islam, nothing further from the possibility of simply stopping the historical engine and trying o understand its mechanism and components without a single glance at immediately later times (the already known future of those processes), not to mention glances at current events or the risk of getting bogged down in a mixture of theology, culture and applied Philology. It is therefore completely logical the lengthy counting of interpretation attempts, as well as the natural incompatibility of these. As Chase F. Robinson puts it, historians of early Islam have found something akin to the French Revolution: a watershed event that stubbornly resists definitive interpretation (1992:741).

In his Introduction to Duri's book, Fred Donner mentions the uncertainties about the reliability of written sources in early Islamic history; uncertainties considered a genuine plague or ominous cloud since the mid-nineteenth century with little sign of dispersing even today. In this very same page, Donner adds: and much fundamental spadework remains to be done before the full outlines of early Islamic history will begin to emerge clearly (Duri 1983:viii). It is true that Donner, afterwards, admits the generally reliable character of the process (Duri 1983: xiv), most of all after quoting the works of Abd Al-Aziz Duri and Nabia Abbott. At any rate, whether one may bet on the reliability of a certain later historian -like al-Waqidi (m.822) for De Goeje since 1864- or cast a shadow of doubt on the reliability of all historical accounts -like Goldziher did since 1888 (Duri 1983: ix)- most scholars, from then on, may all agree in what actually happened (Duri 1983: xvi), but a question remains: who did it and why. Because in all the known and quoted accounts of what may have happened in the Middle East, Iran and North Africa at those times, the subject of the sentence -as I said before- changes from one event to another, and (above all) it is really hard to see a prophetical induction in that big amount of war actions from the very beginning without resorting to the help of the already mentioned 'retrospective narrative'. Do we still have to call all these disconnected formative events just parts, chapters, of a global Arab or Islamic Fath?

I do believe that relevant scholarship on the subject has contributed definitely to distinguish between the forest and the trees (Robinson 1992:741), but I still humbly think that key questions remain decontextualized, specifically while regarding the variety of trees in front of us. And here lies precisely the third main outline of this reflection paper. Being the first one the opportunity of 
thinking about Islam as the effect and not the cause of a convulsive time, and the second one the opening of a long historical period of fallow and formative improvisation (Islamic Late Antiquity, 300-750), the third one would be the necessity of changing 'the ends of the funnel' regarding unity and diversity. Islamic cultural and religious unity come after a long period of heterogeneity, mosaic diversity and not at all vice versa, with all those official accounts around family knots and fitna. The recurrent salvific backward glance, looking back at 'Lost Paradises' of purity and unity can be understood in the field of human spiritual sensitivity or refreshing myths of origin, but not while clearly appearing in front of us evidences of multifaceted formative times, whether we deal with religious systems, deep and enduring cultural projects or even 'natural' languages (from dialects to fuṣhà, and not the other way round, for instance).

\section{Recapitulation theory}

The strategic concept of VUCA (previously, for military use) -Volatility, Uncertainty, Complexity, Ambiguity- is used to face the 'threatening' unpredictability of the present: Volatility (opened dynamics of change), Uncertainty (prospects for surprise), Complexity (multiplicity of forces that surround an organization), and Ambiguity (natural and usual haziness of reality). VUCA is certainly an excellent way to avoid or mitigate the already mentioned street-light effect while searching for something. The reaction in front of the unknown is not necessarily a pendulum between mythical explanation and headache. There may be also the alternative to recognize the complexity of things. And interestingly enough, unpredictability is not one of the main parameters while dealing with the past. And this is interesting, bearing in mind the past was once a certain present, and every present is equally unpredictable. That is to say: how can we expect a linear path in the past (causality) unless that path is traced from the present (the effect)? Past is linear, and future is ramified (i.e. unpredictable, a VUCA theory matter). And so, any line, any kind of linear explanation of the past is by definition a narrative traced from the present, or from any later stage in relation with the events narrated.

This is generally known as 'presentism' or 'fallacy of nunc pro tunc' (the 'now' for 'then'), implying that actors of a time are dressed up anachronistically. I share -by and large- the idea that it was precisely a later (medieval) psychological gap the reason to build up a whole system of narratives describing a previous physical gap ( futūh $h$ ) while dealing with Islam, substituting old multifaceted antagonisms, and recharging them in religious terms. It is John Tolan who asserts, for instance, that (t)he construction of a 
polemical image of Saracens started before the rise of Islam (Tolan 2002:XIX), highlighting -accurately and necessarily- fallacious synonyms in that already mentioned recurrent game of overloading terms (Saracens = Muslims?). There are traces of an undeniable presentism projected from the Middle Ages (for the very first time, and not for the last one) while writing the history of Islamic Late Antiquity, a time -those Middle Ages- of settled 'religionism' (Hull 2000:75) and increasing bipolarity between Christendom and Islam, a situation that will reach its highest level with the apologetic Christian and Muslim literature that made possible the ideological explanation and wrapping up of both Crusade and Jihad, as intertwined concepts with mutual meaning feedback: a concept of Crusade that was born in Romania (Byzantium) (Flori 2004:8) long before early Islam, and a concept of Jihad that cannot mean 'war' in the Qur'an (of course, there is war in the Qur'an, but not under the root J-H-D) (Gonzalez 2005).

Applying that needed VUCA reading -that needed acceptance of the unpredictability of the present- the unpredictable time of Islamic Late Antiquity is a period of seeding, a formative phase. Long decades of creative symbioses of entities only afterwards consolidated and recognizable as separate communities of Jews and Muslims (Wasserstrom 1995: 43, and 216), as well as Christians and also Manichaean and the whole spectrum of possible midlands in between. Those were the times of genuine Polidoxy, of borderlines in terms of burred frontiers (Boyarin 2006). Taking all this into account, how can we focus exclusively on a certain 'alien third person' that comes from the desert, already barricaded with a minted and proper History of Salvation as well as miraculous cavalries? Again: streetlight effect.

Coming back for a while to the illustrious matrix of Islam, there is another biological concept that serves in some authors (Jean Flori, for instance) to explain the misuse of late chronicles' argumentation for previous narrative purposes (i.e. retrospective narrative in action). The concept is Recapitulation. In practice, it comes to mean exactly that matrix of Islam: history was heralded and announced by the very words of the Prophet (history of Salvation, Heilsgeschichte). For Flori, it tends to imply the same: attributing to one and only prophecy the whole series of historical events (Flori 2010:80). Aren't we thinking history in the same way, while concatenating futūh as steps in which several actors merge their roles in order to give prominence to what later historians will think it was already Islam?

Historiology is a 'no man's land' in which Philology is at the service of History and (accepting and revering Gödel's idea of fertile incompleteness), is in continuous need for other auxiliary sciences: in order to avoid 'recapitulation' and 'presentism', we have to deal with the past as if there was no chronological continuation to what we are studying. Trying to understand the all-around 
perplexity of that moment and that present, that VUCA environment. Avoiding 'retrospective narratives'; writing that historical narrative with the only help of primary sources (closest to the events narrated) and contextualized by the unique settings and framing of other disciplines that study those same times from other points of view (Archaeology, Numismatics, History of Arts, Comparative Religions...), just like honest Historiology and common sense recommend.

\section{Actors and chronicles}

At least, two significant things are said to have taken place around year 570: one is the commonly admitted birth date of Prophet Muhammad (conventionally admitted, it has to be added; without much discussion about). The other one is somewhat less legendary: the ultimate destruction of the Maarib dam (in the heart of Yemen), which seems to have led to the northbound emigration of several inhabitants. Thousands of immigrants, presumably following the caravan routes of Arabia. A good starting point for a given hypothetical social change in the core of the Arabian Peninsula: depopulation of southern Arabia and northbound migration. There are literally thousands of inscriptions recording the rich variety of akin Semitic languages spoken and written there (see the Corpus of South Arabian Inscriptions). We may connect some undoubtedly related events as if we did not have access to any late Arabic chronicle, and thus running away from presentism: that migration in 570, the Persian conquest of Jerusalem in 614, and another Persian conquest: Alexandria in 621. In the chronicles of those times, the 'subject of invasion' is the Persian Empire, the Sassanid, and so we collect the fact in the chronicles of those times.

According to the Byzantine chronicles that recount the Persian progress, the end of the world is coming (Avni 2010:35). The long confrontation between Romania (Byzantium) and Persia incorporated from the very beginning the engagement of local peoples and tribes surrounding the vast line from central Arabia to the north, the basin of Tigris and Euphrates; pressing and pushing on them, ones against the others. I wonder what happened when these two Empires, exhausted, gave up direct war around the cornerstone battle of Nineveh in 627 , with a Persian Empire divided and a Byzantine Empire retracted. I wonder to what tasks would devote themselves those peoples and tribes that previously lived for fighting, for war, now that they were discharged. I wonder what could have thought any inhabitant of those so many 'Pillars of Wisdom', so many old and wise cities in the Ancient Middle East, the next time a similar -or perhaps even the same- people came to plunder the city. Could this thought be 'once again'? Could it rather be: 'this is new: it's a brand new time of futū $h$ '? 
Since the early 600 s, every literate and productive person in the Middle East agrees that the discontinuous and multifaceted chain of war actions that whips their time is a divine punishment, but they all disagree or differ while designating the guilty (Flori 2010: 101). And here we could definitely turn to those other mentioned historiographical sources: the chronicles of their times; pre-Islamic chronicles (because they still do not mention Islam). Many of their authors will contend that some Jews have pushed the rebels Saracens. Some of them would rather point at the Assyrians or Chaldeans, even Gog and Magog; the narratives of uncertainty are to that extent, mythographic. 'Rebels Saracens': a good approach, that of rebellion, by the way. And through the Chronicle by Sophronius, Bishop of Jerusalem, we know that he wanted that the imperial troops would come and submit the mad arrogance of the Saracens, thus humiliating them under the feet of the Emperor, as before (Flori 2010: 100). Isn't Sophronius alluding to preceding same-case lootings? 'pre-Futū $h^{\text {' }}$ disorders? Were the previous ones provoked by Saracens by themselves or following Persian orders, pointing, in this case, at a convulsive continuity in the Middle East with this second wave? If this is the case, dates are forcing the very concept of 'prophetic call'. And thus the 'matrix of Islam' or the causative conception of early Islam is a forgery (or another literary genre).

Furthermore, the European pilgrim Arculf witnessed some strange neoJewish manners in the Middle East, as in the famous testimony that the Jews are removing debris on the Temple Mount. These works on the Temple Mount, with the apocalyptic flavor of reconstructing the Temple for the end of times, are perceived at those days as the 'abomination of desolation' prophesied by Daniel as a clear sign of impending fatal Doom (Flusin 1992: 25). Some Adventist Jews rebuilt the Temple, but subsequent (later) Arabic chronicles describe in their own way (presentism) what kind of construction finally appeared. And we assume a governmental -califal- budget and works execution.

In the set of around thirty pre-Islamic chronicles that 'broadcasted' and surveyed those facts, the most outstanding in terms of -precisely- pre-Islamic overtones (i.e. unfamiliar with what could mean afterwards an alien culture coming from the desert), are the following -the year precedes the title, and we will highlight the term used to name the 'looters' -:

634- Doctrina Iacobi, the teachings of the ex-Jewish Jacob, who as a young man amused himself by beating up Christians. Strong anti-Jewish Carthaginian text.

639- The Chronicle of Sophronius, Patriarch of Jerusalem (Saracens).

642- The papyrus PERF 558, written in Greek and with a really interesting Arabic portion. The information in Greek speaks of tributes to the Magharitae and Saracens. 
648- The Life of Gabriel of Qartmin (a monastery in modern Turkey), which talks about some occupants: children of Hagar.

659- Ishoyahb of Adiabene -a region south of Lake Van-, mentions in his letters the Tayyaye and, also, the Mhaggre -possibly immigrants-.

660- Armenian Chronicle of Sebeos, which explains the partnership between the sons of Ishmael and the Jews, for they are -he explains- all descendants of Abraham.

662- Maximus the Confessor, the disciple of Sophronius of Jerusalem, which accuses the Jews of provoking the disorders amongst the peoples in the desert.

665- The testimony of the Coptic Pope of Egypt Benjamin I: he lived the Persian conquest of Alexandria, and later the Byzantine conquest - he was exiled then- and was reinstated in his siege by the Arabs.

670- The already mentioned Arculf the pilgrim. References in the chronicles of Bede the Venerable: some Jews are removing the rubble of the Temple Mount in Jerusalem.

680- George of Reshaina. He blames Maximus for the wrath of God that has enabled the Arabs to control Africa - presumably around current Tunisia- and Cyprus. This George clearly alludes to the emergence of Arabs or Chaldeans or Ishmaelites, as a result of a disorder, not a cause of it (Levy-Rubin 2001:288).

680- A Jewish apocalypse attributed (of course, a literary reverie) to Simon Bar Yohai (year $70 \mathrm{CE}$ !). Children of Ishmael are coming, as the signal that Israel will enter soon to its salvation. The prophecies have been accomplished.

680- The Bundahishn or 'first creation' -a Zoroastrian encyclopedia written in Pahlavi-, speaks of Tadjiks and heterodoxy.

681- The Trophies (actually achievements, victories) raised against the Jews of Damascus, an evident anti-Jewish Greek chronicle: attacks of the Saracens as part of an alliance of Jewish clans against the Byzantines (Luckyn 2010: 162).

687- Athanasius of Balad, Patriarch of Antioch, described in a letter some orgiastic ceremonies in which women and men took part, following the 'ritual sacrifices' of Hagarens (Friedenreicht 2009: 91), whatever that may mean.

687- John Bar Penkaye, at the end of Book 14 of its Synthesis of World History, written in Syriac. He begins to recount the events of his time in the book, and at the climax of book 14, the author speaks of the children of Hagar in the land of the Persians and how they came by God's command and dominated everywhere, but not through war and battles, but in a more subtle way. Like when you take an iron and remove it from the heat (Brock 1987: 51).

694- The Egyptian Chronicle of Coptic Bishop John of Nikiu, describing the situation as fair divine vengeance for the illustrious sins of Chalcedon -year 451-. 
Late seventh century descriptions in the Syriac Apocalypse of PseudoMethodius describing the arrival of the peoples of Gog and Magog (Martinez 1985).

Another Syriac Apocalypse: the Pseudo-Ephraim, describing a prophecy whereby a people will rise from the desert: the offspring of the sons of Hagar.

Jews, Saracens, Magharitae, Children of Hagar, Tayyaye, Sons of Ishmael, Arabs, Chaldeans, Assyrians, Children of Ishmael, Tajiks, Jewish clans, Hagarens, and even the peoples of Gog and Magog... The issue seems highly complex to us, but no less innovative in terms of possible interpretation. I think it is not fair or scientific to translate all those different names as simply 'Muslims' or 'Arabs'.

In these chronicles it is perceived clearly that something happens and the Roman order has disappeared. Government troops are gone. Each part of those 'abandoned lands' is described in the apocalyptic key that best conforms to their perception of the facts. But why should we force ourselves to understand that this time of disaster is a single process induced by a similar single force, directed from the invasive centers in Mecca, Medina, and afterwards Damascus? Because we braid altogether the history of those times, with the evolution of Islam as a religious system, and also with the autopoietic orthodox Islamic account of the facts, made up long afterwards.

Again: why does everybody translate all these names as 'Muslims', when the attackers do not introduce themselves and they even appear as dumb, muted. Clearly, these numerous invaders seem to be waiting for his voice in Arabic, a century later. Does anybody ever -for instance- make reference to all this as a unique and central force called 'Jewish Futūh' as another way of speculating and labelling, simply based on the majority of the allusions? No one has ever found a first person account of these voiceless actions, of this 'invisible conquest' (Pentz 1992).

At any case, even though we can track a juxtaposed bunch of peoples, there can be a sort of greatest common multiple in order to 'translate in a set' -nomad peoples, raiders- or even another least common denominator in order to understand the causes - disappearance of centralized governments, either Romania or Persia-. What definitely is not there at all is the term Islam, or Muslim, or even Qur'an.

\section{Islamic Late Antiquity}

Disregarding the dogmatic and positivist (historicist) sequence of facts as dictated by the official historical Islam -founder, early expansion due to a prophetic call, encounter with 'others'-, in reality there is no testimony of Islam 
until much later. I'd rather point at the foundation of the 'City of Peace' as a visible starting point, but of course in history nothing arises all of a sudden: before that date (762), there are historical traces of sporadic conjunction of elements as the resuming trade, several essays of regional strong currency till arriving at a tacit 'dinar standard', not necessarily associated with Islamization (and not even with general Arabization of the lands: there will be dinars in Arabic minted in South England, for instance). Of course, a legend minted in a coin that reads something like 'there is no more than one God' can be any loose anti-Trinitarian creed emerged from any corner of that multifaceted Middle East, with no necessity of an alienating consideration of a new religious system and its autopoietic explanation.

In Historiological terms, facts are facts and do not change. But the way we frame them, the paradigm we establish to contemplate them in movement, this is always changing. Islam is the result of several historical facts and circumstances, not necessarily connected beforehand. There is no need of maintaining unexplained - outlandish- considerations simply because we fear to manage ambiguity, to count on it. But this - ambiguity- is indeed the keystone in Historiological approaches: concepts like conversion, religion, cultural system, as well as all their possible associations and related semantic fields related, all these change from time to time, to the point that it is -for instance-completely absurd talking about 'conversion' in Late Antiquity as we understand the term today. Or talking about 'religious ideology'.

Apart from presentist ideological reasons, there is no reason or need of maintaining the jump from Late Antiquity to the Middle Ages like a historical abduction by means of an unexpected invasion that inoculated a strange cultural system from the deserts of the Middle East. The use of the expression 'Islamic Late Antiquity', as well as its intellectual consideration, can open the habitual reductionism with which we tend to install historical gaps. We are dealing with the period most commonly recognized as unknown (Wasserstrom 1995: 17), and it is not by lack of information, but rather by an erroneous paradigm (a surmountable one) based on presentism and recapitulation; two patterns that invalidate enough ambiguity and comparative studies needed to understand Early Islam, the formative period of Islam till its historical birth, and not its first steps once born. 


\section{References:}

Arié, Rachel (1984), España musulmana (siglos VIII-XV). Barcelona: Labor, Historia de España III.

Avni, Gideon (2010), 'The Persian Conquest of Jerusalem (614 c.e.)- An Archaeological Assessment'. Bulletin of the American Schools of Oriental Research 357, 35-48.

Bashear, Suliman (1997), Arabs and Others in Early Islam. Princeton: Darwin Press (Studies in Late Antiquity and Early Islam -SLAEI-, 8) (Jerusalem 1984 in Arabic)

Beckwith, Christopher I. (2009), Empires of the Silk Road. A History of Central Eurasia from the Bronze Age to the Present. Princeton U.P.

Boyarin, Daniel (2006), Border-Lines: the Partition of Judaeo-Christianity. Filadelfia: University of Pennsilvania Press.

Brock, Sebastian (1987), 'North Mesopotamia in the late seventh century: Book XV of John Bar Penkayé's Rish Melle', Jerusalem Studies in Arabic and Islam 9, 51-75.

Duri, Abd Al-Aziz (1983), The Rise of Historical Writing Among the Arabs. Princeton U.P.

Flori, Jean (2004), Guerra Santa, Yihad, Cruzada. Violencia y religión en el cristianismo y en el islam. University of Granada / University of Valencia.

Flori, Jean (2010), El islam y el fin de los tiempos. La interpretación profética de las invasiones musumanas en la Cristiandad medieval. Madrid: Akal.

Flusin, B. (1992), 'L'Esplanade du Temple à l'arrivée des Arabes, d'aprés deux récits byzantines'. In: J. Raby e I. Johns (Eds.), Bayt al-Maqdis. Oxford U.P., pp. 25-26.

Friedenreicht, David M. (2009), 'Muslims in Canon Law, 650-1000'. In: David Thomas and Barbara Roggema (Eds.), Christian-Muslim Relations. A Historical Bibliography. (Vol. I, 600-900). Leiden: Brill, 83-98.

Gonzalez-Ferrin, Emilio (2005), 'La palabra descendida y la guerra'. Cuadernos del CEMYR (Centro de Estudios Medievales y Renacentistas). University of La Laguna.

Heidegger, Martin (2011), The Concept of Time: The First Draft of Being and Time. London: Continuum.

Hull, John M. (2000), 'Religionism and Religious Education'. In: Mal Leicester (et. al.) (eds.), Education, Culture and Values: Spiritual and Religious Education, vol. 5. London: Falmer Press, 75-85. 
Levy-Rubin, Milka (2001), 'The Role of the Judaean Desert Monasteries in the Monothelite Controversy in Seventh Century Palestine'. In: Joseph Patrick (Ed.), The Sabaite Heritage in the Orthodox Church from the Fifth Century to the Present. Lovain: Peeters (Orientalia Lovainensia Analecta), 283-300.

Luckyn Williams, A. (2010), Adversus Judaeos. A Bird's-Eye View of Christian Apologiae Until the Renaissance. Londres: Cambridge U.P. (1935'1).

Martinez, Francisco Javier (1985), Eastern Christian Apocalyptic in the Early Muslim Period: Pseudo-Methodius and Pseudo-Athanasius. Washington: The Catholic University of America.

Pentz, Peter (1992), The Invisible Conquest: The Ontogenesis of Sixth and Seventh Century Syria. Copenhagen: The National Museum of Denmark/ Collection of Near Eastern and Classical Antiquities.

Reinhart, A. Kevin (2003), 'On the "Introduction to Islam"'. In: Brannon M. Wheeler (Ed.) Teaching Islam. Oxford U.P., 22-45.

Robinson, Chase F. (1992), Review of John W. Jandora, The March From Medina... International Journal of Middle East Studies 24, 4. 741-742.

Sfeir, Antoine (2013), L'islam contre l'islam. L'interminable guerre des sunnites et des chiites. Paris: Grasset.

Sizgorich, Thomas (2004), 'Narrative and Community in Islamic Late Antiquity'. Past \& Present 185, 9-42.

Tolan, John V. (2002), Saracens: Islam in the Medieval European Imagination. New York: Columbia U.P.

Wasserstrom, Steven M. (1995), Between Muslim and Jew: the Problem of Symbiosis under Early Islam. Galliard: Princeton University Press.

Weick, K.E. (1987), 'Substitutes for Strategy'. In: D.J. Teece (Ed.), The Competitive Challenge: Strategies for Industrial Innovation and Renewal. Cambridge: M.A. Ballinger, 221-233.

Weitzmann, Kurt, (Ed.) (1979), Age of Spirituality: Late Antique and Early Christian Art, Third to Seventh Century. New York: The Metropolitan Museum of Art 
